\title{
Characterization of murine amniotic fluid B cells in normal pregnancy and in preterm birth
}

\author{
Imke Bommer ${ }^{1}$, Lorena Juriol ${ }^{2}$, Damián Muzzioํ, Natalin Valeff², Jens Ehrhardt ${ }^{1}$, \\ Franziska Matzner ${ }^{1}$, Katharina Ziegler ${ }^{1}$, Kristin Malinowsky ${ }^{1}$, María Silvia Ventimiglia², \\ Marek Zygmunt ${ }^{1}$ and Federico Jensen ${ }^{1,2,3}$ \\ ${ }^{1}$ Department of Obstetrics and Gynecology, Research Laboratory, University of Greifswald, Greifswald, Germany, \\ ${ }^{2}$ Laboratory for Immunology of Pregnancy, Center for Pharmacological and Botanical Studies \\ (CEFYBO-CONICET-UBA), Buenos Aires, Argentina and ${ }^{3}$ Institute of Health Sciences, National University Arturo \\ Jauretche, Buenos Aires, Argentina
}

Correspondence should be addressed to F Jensen; Email: fjensen@unaj.edu.ar

\begin{abstract}
The amniotic fluid provides mechanical protection and immune defense against pathogens to the fetus. Indeed, components of the innate and adaptive immunity, including B cells, have been described in the amniotic fluid. However, limited information concerning phenotype and functionality of amniotic fluid B cells is available. Hence, we aimed to perform a full phenotypical and functional characterization of amniotic fluid B cells in normal pregnancy and in a mouse model of preterm birth. Phenotypic analysis depicted the presence of two populations of amniotic fluid B cells: an immature population, resembling B1 progenitor cells and a more mature population. Further isolation and in vitro co-culture with a bone marrow stroma cell line demonstrated the capacity of the immature B cells to mature. This was further supported by spontaneous production of IgM, a feature of the B1 B cell sub-population. An additional in vitro stimulation with lipopolysaccharide induced the activation of amniotic fluid B cells as well as the production of pro and anti-inflammatory cytokines. Furthermore, amniotic fluid B cells were expanded in the acute phase of LPS-induced preterm birth. Overall our data add new insight not only on the phenotype and developmental stage of the amniotic fluid B1 B cells but especially on their functionality. This provides important information for a better understanding of their role within the amniotic fluid as immunological protective barrier, especially with regard to intraamniotic infection and preterm birth.

Reproduction (2019) 158 369-376
\end{abstract}

\section{Introduction}

The amniotic sac is a placental structure of fetal origin that contains a regulated amount of fluid, the amniotic fluid. It is forming a mechanical protection to the fetus against physical trauma and provides nutrients and factors required for fetal growth (Underwood et al. 2005). In addition, it represents a critical immune barrier that protects the fetus against pathogens. Indeed, it is known that the AF contains leukocytes as well as proteins implicated in fetal host defense (Galask \& Snyder 1970, Schlievert et al. 1976, 1977, Tafari et al. 1977, Larsen et al. 1979, Niemelä et al. 1989, Pierce et al. 2016). It has also been shown that immune cells, including B cells are constantly present within the amniotic fluid during all stages of pregnancy (Gomez-Lopez et al. 2018b). In women undergoing intraamniotic inflammation, caused either by intraamniotic infection, external signals or cellular stress, the numbers of leukocytes as well as the concentration of inflammatory mediators, such as cytokines and antimicrobial peptides, are significantly increased in the AF (Romero et al. 2011, Gomez-Lopez et al. 2018b). In this regard, it has been shown that the numbers of immune cells are significantly higher in the $\mathrm{AF}$ of pregnant women suffering from intraamniotic infections, which implicates that the innate as well as the adaptive immune system are involved in the pathogenesis of preterm birth (Gomez-Lopez et al. 2016, 2017, Arenas-Hernandez et al. 2019, Leng et al. 2019).

B cells are pleiotropic cells of the adaptive arm of the immune system with the unique ability to give rise to fully differentiated immunoglobulin-producing cell (Pieper et al. 2013). In addition to this critical function, $B$ cells can also present antigens to $T$ cells and produce a wide range of cytokines (Lund 2008). Based on their functionality, localization and developmental origin, B cells can be divided into B1 and B2 B cells (MontecinoRodriguez \& Dorshkind 2012). While B2 B cells are continuously produced during the postnatal life from precursors located in the bone marrow, B1 B cells arise mainly during the embryonic life from progenitor cells initially located in the extra-embryonic membranes and then in the embryonic liver (Montecino-Rodriguez \& 
Dorshkind 2012). During their development B1 B cells undergo various changes of surface antigen expression. Roughly it has been described that during the process of maturation an upregulation of CD45R(B220) and slgM takes place so that in this context there are two phenotypes that are to be distinguished. The one of CD19 ${ }^{+}$B220 low/neg $\mathrm{B}$ cell progenitors and a more mature $\mathrm{CD}_{19}{ }^{+} \mathrm{B}_{220^{+}} \mathrm{slgM}{ }^{+}$phenotype (Montecino-Rodriguez \& Dorshkind 2012).

Our group and others have demonstrated that B cell development and function undergo profound modifications during pregnancy, most likely to allow the presence of the semi-allogeneic fetus (Medina et al. 1993, Kincade et al. 1994, Muzzio et al. 2014, Ziegler et al. 2018). Moreover, it has also been demonstrated that $\mathrm{B}$ cells are critically involved in pregnancy associated pathologies like preeclampsia and preterm birth (Jensen et al. 2013, Huang et al. 2017, Leng et al. 2019). Furthermore, the presence of B cells in reproductive tissues including amniotic fluid has already been described (Huang et al. 2017, Gomez-Lopez et al. 2018a).

Hence, we aimed in this study to perform a full phenotypical and functional characterization of the amniotic fluid B cells in normal pregnancy in mice as well as in a mouse model of preterm birth.

\section{Material and methods Animals}

Females BALB/C or C57BL/6 (inbred strain) and males C57BL/6 or BALB/C (inbred strain) mice at 8-12 weeks of age were provided by the ZSFV (Zentrale Service und Forschungseinrichtung für Versuchstiere) in Greifswald. All mice were maintained in the facilities of the BioTechnikum Greifswald under a 12-h light/12-h darkness cycle and were given ad libitum access to food and water. Animal experiments were carried out according to institutional guidelines after ministerial approval (Landesamt für Landwirtschaft, Lebensmittelsicherheit und Fischerei Mecklenburg-Vorpommern (7221.3-1-068/13 to $\mathrm{F}$ J)). The experiments were conducted in conformity with the European Communities Council Directive 86/609/EEC.

Virgin $\mathrm{BALB} / \mathrm{C}\left(\mathrm{H}-2 \mathrm{D}^{\mathrm{d}}\right)$ or $\mathrm{C} 57 \mathrm{BL} / 6\left(\mathrm{H}-2 \mathrm{D}^{\mathrm{b}}\right)$ females were mated $1: 1$ with $\mathrm{C} 57 \mathrm{BL} / 6\left(\mathrm{H}-2 \mathrm{D}^{\mathrm{b}}\right)$ or $\mathrm{BALB} / \mathrm{C}\left(\mathrm{H}-2 \mathrm{D}^{\mathrm{d}}\right)$ males respectively until pregnancy was confirmed. The presence of a vaginal plug was designated as day 0 of pregnancy. Pregnant animals were killed at day 14 of pregnancy, individual amniotic sacs were removed from the maternal uterus and the AF collected as shown in Fig. 1. To avoid contamination with maternal cells, only clear, transparent fluids were used for the experiments.

For experiments displayed in Fig. 1, C57BL/6 females were mated with BALB/C males. Pregnant females were systemically challenged (i.p.) at day 15 of pregnancy with a single dose of LPS $(10 \mu \mathrm{g} / \mathrm{mice})$ or PBS as control. Animals were killed $5 \mathrm{~h}$ after LPS injection and the AF was collected. The dose of LPS used in this work caused $100 \%$ preterm birth (PTB; Huang et al. 2017, unpublished data from our laboratory).

\section{Isolation of $B$ cells from $A F$}

$\mathrm{AFCD} 9^{+}$cells were magnetically isolated using a commercially available kit (MACS). Briefly, AF was applied onto a $100 \mu \mathrm{m}$ cell strainer to obtain a single cell suspension. Obtained cells were magnetically labeled with CD19 MicroBeads (Miltenyi Biotec) and then retained in a MACS column placed in a MACS separator. The retained $\mathrm{CD} 19^{+}$cells were then eluted and collected as the enriched positively selected cell fraction. Purity in all experiments was up to $90 \%$.

\section{Cell culture and in vitro stimulation}

Isolated CD19+ AF cells (5000-9000 cells) were placed in a six-well plate that was pre-coated with a bone marrow stromal cell line (OP9) the day before. Cells were co-cultured in $2 \mathrm{ml}$
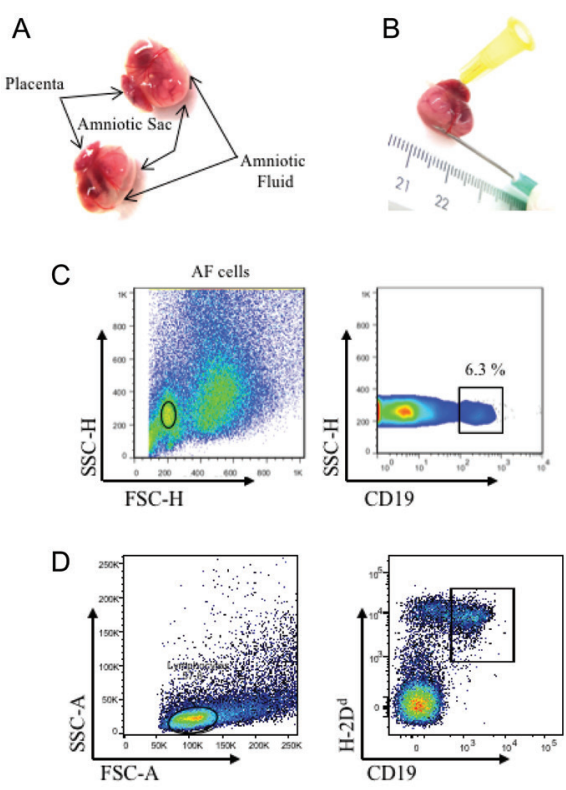

E AF isolated $\mathrm{CD}^{2} 9^{+} \mathrm{B}$ cells

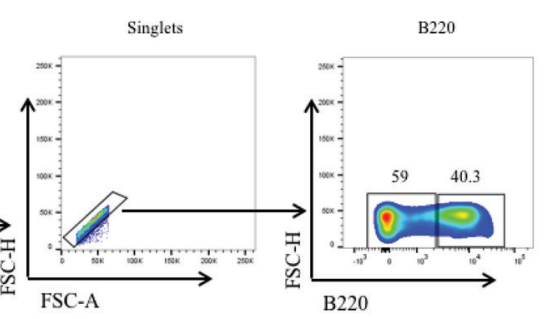

Figure 1 Isolation and characterization of AF cells. (A) Murine feto-maternal unit after removal from the maternal uterus, showing the placenta and the amniotic sac containing the AF. (B) Collection of the AF with a $0.6 \times 25 \mathrm{~mm}$ syringe (green). (C) Gating strategy for the flow cytometric analysis of CD19+ AF-B cells. (D) Expression analysis of paternal $\mathrm{MHCl}$ molecule $\left(\mathrm{H}-2 \mathrm{D}^{\mathrm{d}}\right)$ within $\mathrm{CD} 19^{+} \mathrm{AF}-\mathrm{B}$ cells. (E) Pure magnetically isolated CD19+ AF-B cells were stained with fluorochrome-conjugated antibodies against CD45R (B220) and analyzed by flow cytometry. Lymphocytes were identified by their scatter properties (FSC-A $\times$ SSC-A plot or FSC-H $\times$ SSC-H) and then doublets were excluded by gating on FSC-A $\times$ FSC-H. Fluorescence minus one (FMO) was used as control. Data is representative of at least eight independent animals. 
of culture medium per well ( $\alpha$-MEM-medium, 10\% FBS, 1\% Pen/Strep, $5 \times 10^{-5} \mathrm{M} \beta$-Mercaptoethanol, 50 units $/ \mathrm{mL} \mathrm{IL-7}$ and $10 \mathrm{ng} / \mathrm{mL}$ flt-3 ligand) (Yoshimoto et al. 2011) for 10 days at $37^{\circ} \mathrm{C}$ in steam-saturated atmosphere $\left(5 \% \mathrm{CO}_{2}\right)$. The medium was changed every second day. In same experiments, after 10 days in culture, cells were further stimulated with LPS $(10 \mu \mathrm{g} /$ $\mathrm{mL}$; 0111:B4) for 48h, with or without the addition of Phorbol12-myristate-13-acetate (PMA), Ionomycin and Brefeldin A for the last $5 \mathrm{~h}$ of culture.

\section{Cell staining and flow cytometry}

Before staining and to avoid unspecificity, cells were washed twice in FACS buffer (PBS $1 \times+$ BSA $1 \%+0.1$ sodium azide) and incubated with Mouse BD FC Block ${ }^{\mathrm{TM}}$ solution following manufacturer recommendations. Afterward, cells were resuspended in $100 \mu \mathrm{L}$ of FACS buffer containing specific extracellular antibodies (B220 PE (RA3-6B2), $0.2 \mathrm{mg} / \mathrm{mL}$; IgM APC (II/41), $0.2 \mathrm{mg} / \mathrm{mL}$; CD19 PE-Cy7 (1D3), $0.2 \mathrm{mg} / \mathrm{mL}$; CD69 PerCP-Cy5.5 (H1.2F3), 0.2 mg/mL; MHCII FITC (2G9), $0.5 \mathrm{mg} / \mathrm{mL}$; H-2D ${ }^{\mathrm{d}}$ Alexa Fluor 647 (32-2-12), $0.5 \mathrm{mg} / \mathrm{mL}$ ) for $30 \mathrm{~min}$ at $4{ }^{\circ} \mathrm{C}$. For intracellular protein detection, cells were first stained for extracellular markers as explained above and then treated with BD Cytofix/Cytoperm Fixation and
Permeabilization Solution. Next, cells were incubated for 30 min at $4{ }^{\circ} \mathrm{C}$ with $100 \mu \mathrm{L}$ of FACS buffer containing specific antibodies (TNF- $\alpha$ PE (MP6-XT22), $0.2 \mathrm{mg} / \mathrm{mL}$; IFN- $\gamma$ APC (XMG1.2), $0.2 \mathrm{mg} / \mathrm{mL}$ and IL-10 FITC (JES5-16E3), $0.5 \mathrm{mg} / \mathrm{mL}$ ). Unless indicated otherwise, all antibodies were purchased from Biolegends, Germany. Data were acquired on BD FACSCanto $^{\text {TM }}$ or BD-Accuri C6 Plus ${ }^{\mathrm{TM}}$ Flow Cytometers and analyzed by using Flowjo software.

\section{IgM ELISA}

Levels of IgM in the supernatants of the co-culture system were assayed by using a commercially available ELISA Kit (Mouse IgM ELISA 'Ready-Set-Go ${ }^{\prime}$ ', eBioscience) following the supplier's recommendations.

\section{Statistical analysis}

Data were analyzed with PRISM software (version 5.0, GraphPad). T-test or Mann-Whitney test was applied as appropriated to evaluate differences of means. Significant differences between groups were indicated with asterisks $\left({ }^{*} P<0.05 ;{ }^{* *} P<0.01 ; * * * P<0.001\right)$.
A

A Singlets

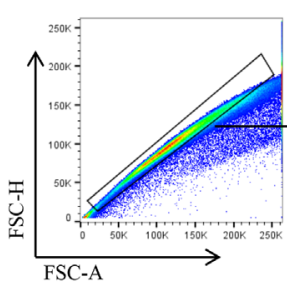

B

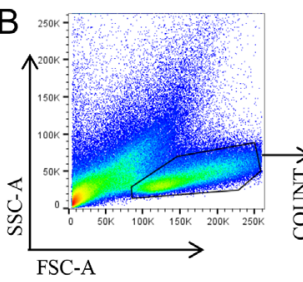

C

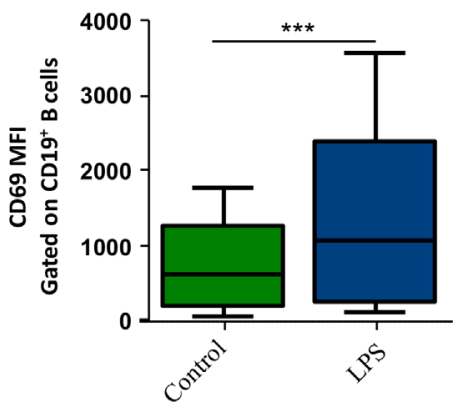

Lymphocytes
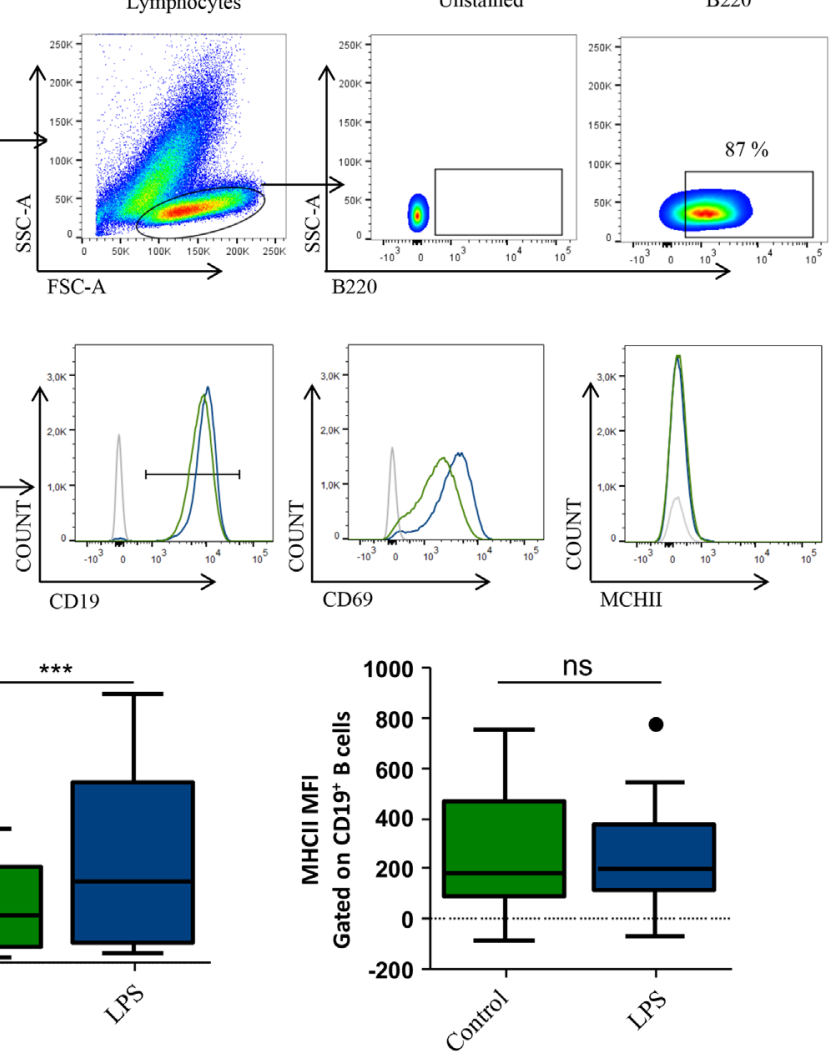

Figure 2 Phenotypic characterization of isolated $\mathrm{AF} \mathrm{CD} 19^{+} \mathrm{B}$ cells co-cultured with a bone marrow stromal cell line. (A) Magnetically isolated CD19+ AF-B cells were co-cultured with a bone marrow stromal cell line (OP9) for 10 days and then stained with fluorochrome-conjugated antibodies against CD45R (B220). (B) Representative histograms showing gating strategy for the analysis of the expression of B cell activation markers, CD69 and $\mathrm{MHCll}$ in $\mathrm{AF}$-isolated $\mathrm{CD} 19^{+}$cells after co-culture with OP9 stromal cell line. Pure isolated CD19+ AF-B cells were co-cultured with OP9 stromal cells for 10 days and then treated with LPS $(10 \mu \mathrm{g} / \mathrm{mL})$ for $48 \mathrm{~h}$. Thereafter, cells were stained with fluorochromeconjugated antibodies against CD19, CD69 and $\mathrm{MHCll}$ and analyzed by flow cytometry using a FACSCanto flow cytometer. Gray histograms represent corresponding unstained controls. (C) Box and whiskers graphs showing mean fluorescence intensity (MFI) of CD69 and $\mathrm{MHCll}$ in $\mathrm{CD} 19^{+} \mathrm{B}$ cells. Data were collected with FACSCanto flow cytometer and analyzed with Flowjo software. Lymphocytes were identified by their scatter properties (FSC-A $\times$ SSC-A plot) and then doublets were excluded by gating on FSC-A $\times$ FSC- $\mathrm{H}$. Fluorescence minus one (FMO) was used as control. Data were analyzed with PRISM software (version 5.0, GraphPad). Data are shown as mean \pm S.E.M. of five mice per group. $* * * P<0.001$ as analyzed by Mann-Whitney test. 


\section{Results}

\section{The amniotic fluid contains B cells in different stages of their development}

We began isolating amniotic fluid cells from the amniotic sac of pregnant mice on day 14 of pregnancy (Fig. 1A and B) and analyzed the presence of CD19+ $\mathrm{B}$ cells by flow cytometry. As shown in Fig. 1C, 6-13\% of the AF lymphocytes were positive for the $\mathrm{B}$ cell antigen CD19 (Fig. 1C). In addition, using a C57BL/6 (female) $\times$ BALB/c (male) breeding strategy, we analyzed the expression of $\mathrm{H}-2 \mathrm{D}^{\mathrm{d}}$ (BALB/C MHCl) in AF-CD19+ cells. As shown in Fig. 1D, the vast majority of the AF-CD $19^{+}$cells expressed paternal $\mathrm{MHCl}$ antigen. Next, in order to perform a more detailed characterization of these cells, we proceeded to magnetically isolate CD19 ${ }^{+}$cells from AF of pregnant mice and perform a phenotypic characterization. The expression analysis of CD45R (B220) in isolated CD19+ AF cells allowed the distinction of two well-defined populations. A B220 expressing $\mathrm{CD} 19^{+}$population of $\mathrm{B}$ cells $\left(\mathrm{CD} 19^{+} \mathrm{B} 220^{+}\right.$; Fig. 1D) and a second population, which was either negative or expressed very low levels of B220
$\left(\mathrm{CD} 19^{+} \mathrm{B} 220^{\text {lo-neg; }}\right.$ Fig. 1D). The latter have already been described as that of fetal B-1 B cell progenitors (Montecino-Rodriguez et al. 2006).

In summary, these results demonstrate the presence, in the AF, of B cells in different stages of their development which additionally express paternal $\mathrm{MHCl}$.

\section{Immature amniotic fluid B cells expand and mature in vitro}

To examine the capacity of AF-B cells to mature in vitro, we next magnetically isolated $\mathrm{CD} 19^{+} \mathrm{B}$ cells from the AF of pregnant mice and co-cultured them with a bone marrow stromal cell line (OP9), which is known to support immature B cell maturation (MontecinoRodriguez et al. 2006, Ji et al. 2008). After 10 days in culture, we observed an extensive proliferation of the CD19+ AF-B cells co-cultured with the OP9 cells (data not showed). Interestingly, phenotype analysis showed that after 10 days in culture, the vast majority of the AF CD19 ${ }^{+}$B cells expressed B220 (Fig. 2A).

Overall, these results show that immature CD19+ AF-B cells are able to phenotypically maturate in vitro.
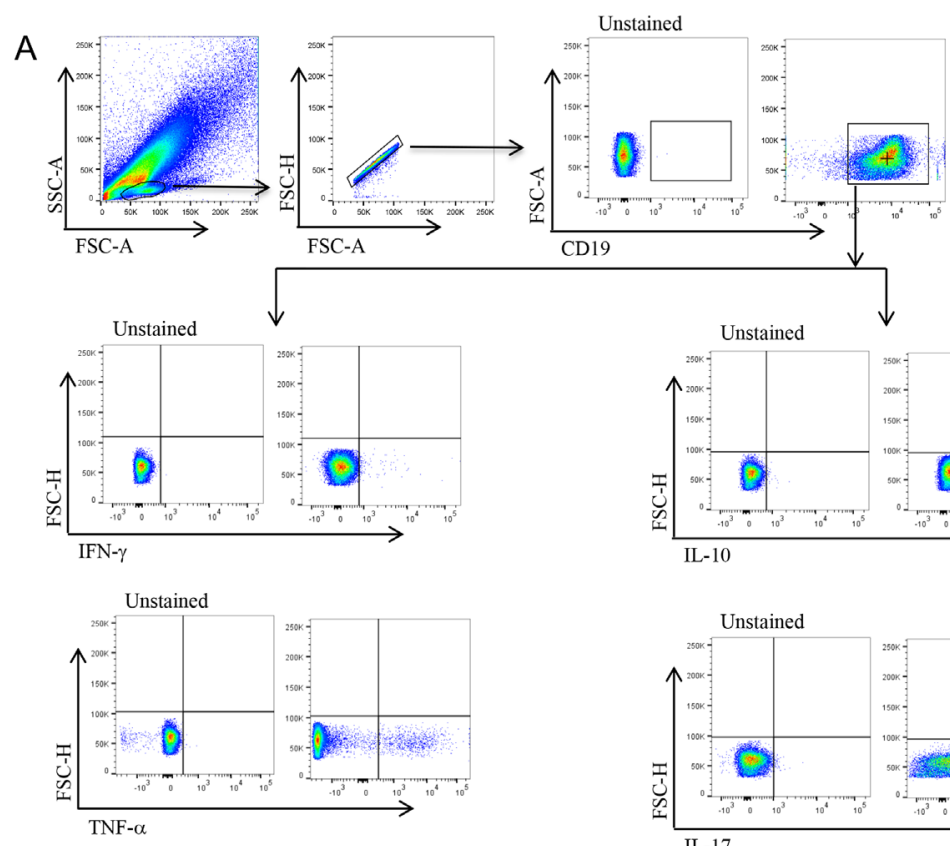

$\mathrm{B}$

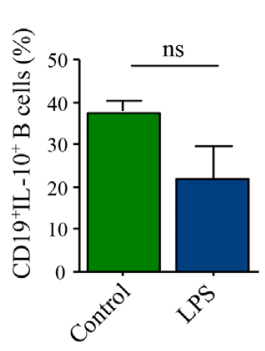

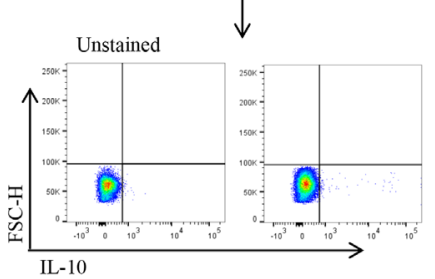
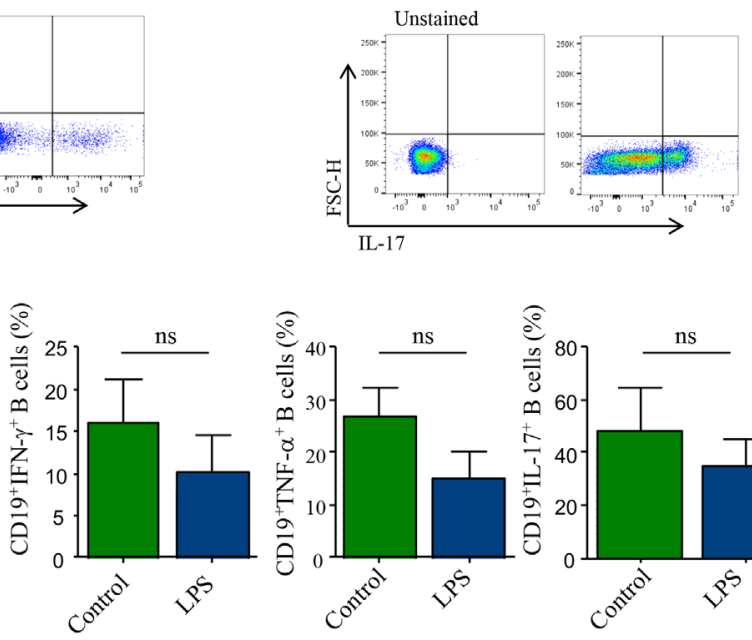

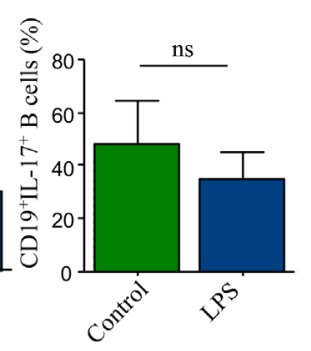

Figure 3 Amniotic fluid $B$ cells produce pro as well as anti-inflammatory cytokines. (A) Representative pseudocolor plots showing gating strategy used to analyze intracellular cytokine production by AF-B cells. Pure isolated $\mathrm{CD} 19^{+} \mathrm{AF}-\mathrm{B}$ cells were co-cultured with OP9 stromal cells for 10 days and then treated with LPS $(10 \mu \mathrm{g} / \mathrm{mL})$ for $48 \mathrm{~h}$. Thereafter, cells were stained with fluorochromeconjugated antibodies against CD19, TNF- $\alpha$, IFN- $\gamma$, IL-17A and IL-10. Data were collected with FACSCanto flow cytometer and analyzed with Flowjo software. Lymphocytes are identified by their scatter properties (FSC-A $\times$ SSC-A plot) and then doublets were excluded by gating on FSC-A $\times$ FSC-H. Data are shown as mean \pm S.E.M. of five mice per group. No statistically significant differences were observed among the groups as analyzed by Student's $t$-test. 


\section{Lipopolysaccharide (LPS) induces the activation of amniotic fluid $B$ cells in vitro}

Knowing that AF-B cells are capable to mature in vitro, we next analyzed whether these cells can also be activated in vitro. To do so, AF CD19+ isolated B cells were co-cultured for 10 days with OP9 bone marrow stromal cells and then further stimulated with LPS for $48 \mathrm{~h}$. As shown in Fig. 2C, we observed a significant increase in the expression of $\mathrm{B}$ cell activation marker CD69 in CD19+ AF-B cells upon LPS stimulation (Fig. $2 \mathrm{~B}$ and $\mathrm{C})$. However, no differences were observed in the expression of MHCII in AF-CD19+ B cells (Fig. 2C). We additionally analyzed intracellular production of pro-inflammatory TNF- $\alpha$, IFN $\gamma$ and IL-17A as well as anti-inflammatory IL-10 cytokines in AF-B cells upon LPS stimulation. No differences were observed related to cytokines production by AF-B cells upon LPS stimulation (Fig. 3). In summary, these results demonstrate that albeit AF-B cells can be activated with LPS in vitro, LPS does not significantly affect the production of IL-10, IFN- $\gamma$, TNF- $\alpha$ and IL-17A by AF-B cells in the conditions we tested.

\section{Amniotic fluid B cells spontaneously produce IgM in vitro}

One of the main features of the B cells compartment is the capacity to give raise to fully differentiated cells (plasma cells) capable to produce antibodies. To investigate whether AF-B cells can differentiate into antibody producing cells, we co-cultured pure isolated AF-CD19+ B cells with OP9 bone marrow stromal cells for 10 days with or without the addition of LPS for the last $48 \mathrm{~h}$. Afterward, levels of IgM were measured in the supernatants. Notably, unstimulated AF-B cells produced detectable quantities of IgM (Fig. 5). Lipopolysaccharide stimulation did not alter the production of IgM by AF-B cells as compared to non-stimulated cells (Fig. 4). In summary, these results illustrate the capacity of the AF-B cells to spontaneously differentiate into IgM producing cells, strongly suggesting that AF-B cells belong to the B1 B cell subset.

\section{Maternal LPS challenge induces an increase in the numbers of amniotic fluid $B$ cells in a mouse model of preterm birth}

In an attempt to evaluate how AF-B cells behave in the context of preterm birth we took advantage of a wellestablished model of LPS-induced PTB. Briefly, pregnant females were systemically challenged (i.p.) with $10 \mu \mathrm{g}$ of LPS on day 15 of pregnancy, a dose that induces $100 \%$ of preterm births (Kaga et al. 1996, Huang et al. 2017, unpublished data from our laboratory) and were killed $5 \mathrm{~h}$ later. As control, pregnant females were injected with sterile PBS (vehicle). We observed that LPS induced a significant increase in the percentages as well as total numbers of $\mathrm{CD} 19^{+}$AF-B cells compared to PBS-treated mice (Fig. 5). Moreover, percentages of B220 expressing CD19+ AF-B cells were significantly increased upon LPS challenge as compared to PBS-treated control mice (Fig. 5). Interestingly, the vast majority of AF-B cells in both groups expressed the B1 B cell marker, CD5.

Overall, the results presented here indicate that the presence of bacterial components in maternal circulation during pregnancy affects the numbers and phenotype of AF-B cells.

\section{Discussion}

In this work, we demonstrated that murine amniotic fluid contains B cells in different stages of development which express paternal $\mathrm{MHCl}$ molecule, suggesting an embryonic origin. Furthermore, we were able to show that AF-B cells can continue their development in vitro, become mature and produce pro- as well as anti-inflammatory cytokines and more importantly spontaneously release IgM.

Based on phenotype, localization and function, B cells can be divided into B1 and B2 subpopulations (Hardy \& Hayakawa 2001). Unlike B1 B cells, which are originated almost exclusively during the embryonic life, B2 B cells are continuously produced throughout

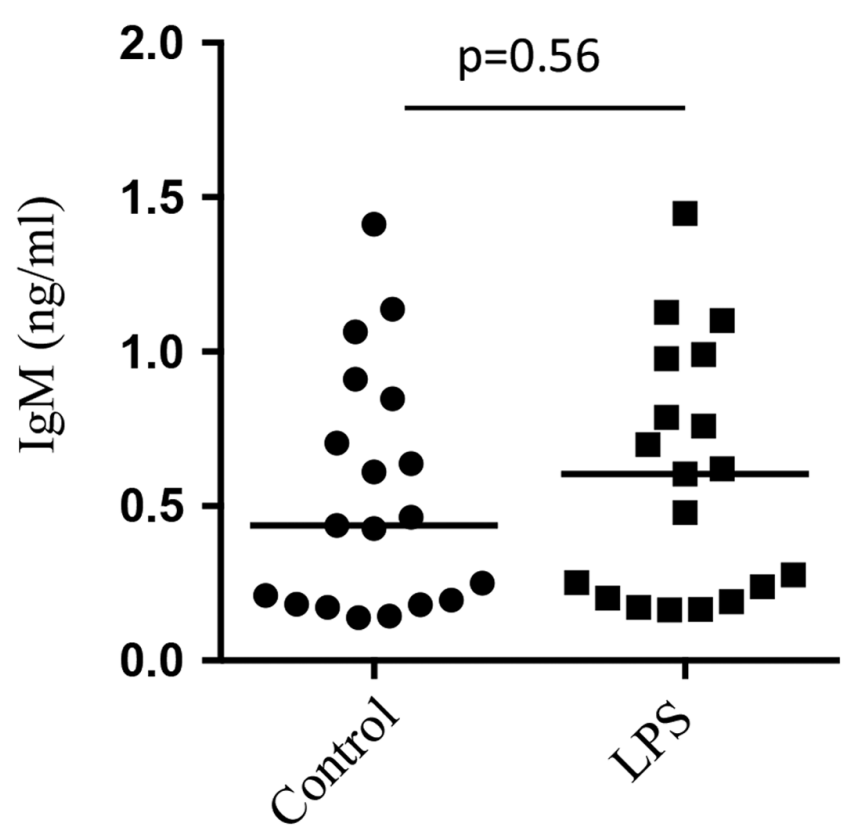

Figure 4 Amniotic fluid B cells spontaneously produce IgM. Pure magnetically isolated CD19+ AF-B cells were co-cultured with OP9 stromal cells for 10 days and then further stimulated with LPS $(10 \mu \mathrm{g} /$ $\mathrm{mL}$ ) for $48 \mathrm{~h}$. Levels of IgM were quantified in supernatants by ELISA. Data are shown as single dot, whereas means are indicated. No statistically significant differences were observed among the groups as analyzed by Mann-Whitney test. 
A
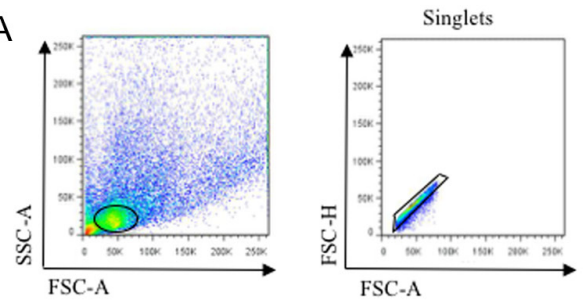

PBS

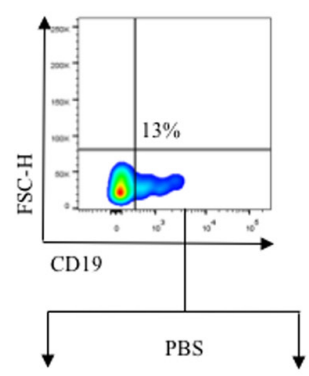

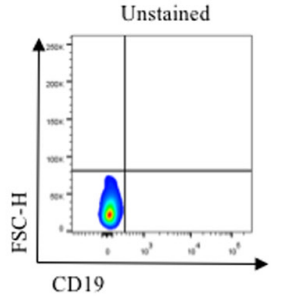

LPS

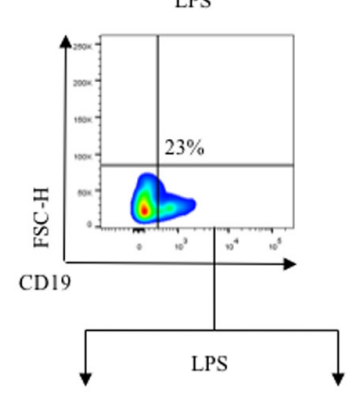

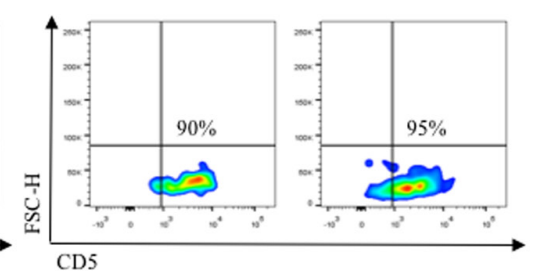

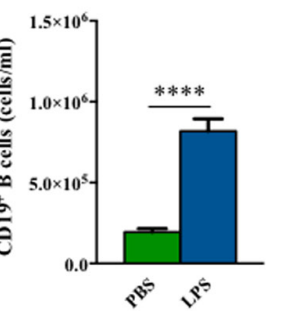

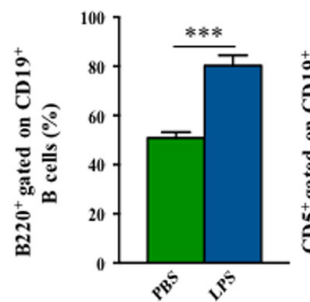
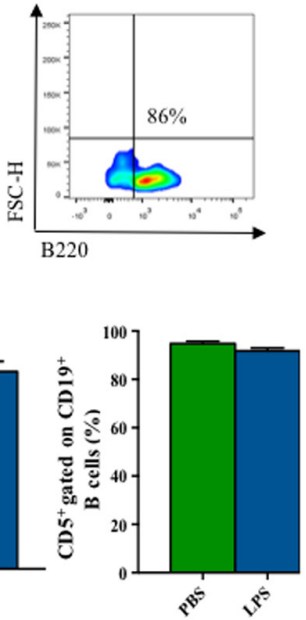

Figure 5 B cells are augmented in the amniotic fluid during acute phase of LPS-induced PTB. Pregnant mice were injected (i.p.) with LPS $(10 \mu \mathrm{g} / \mathrm{mice})$ on day 16 of pregnancy and killed $5 \mathrm{~h}$ later. (A) Representative pseudocolor plots showing gating strategy used to analyze different $B$ cell subpopulations in the AF during acute phase of LPS-induced PTB. (B) Bar graphs show percentages and total numbers of $\mathrm{CD} 19^{+} \mathrm{B}$ cells as well as percentages of CD19-gated B220 and CD19-gated CD5 B1 B cells in the AF during acute phase of LPS-induced PTB. Data are shown as mean \pm S.E.M. of six mice per group. ${ }^{* * *} P<0.001 ;{ }^{* * * *} P<0.0001$ as analyzed by Student's t-test. postnatal life (reviewed in Montecino-Rodriguez \& Dorshkind 2012).

Interestingly, almost half of the AF-B cells described in this work showed a phenotype which resembles that of the B1 B cell progenitors $\left(C D 19^{+}\right.$B220 $0^{\text {low/neg }}$ ) previously described (Montecino-Rodriguez et al. 2006, Yoshimoto et al. 2011). Remarkably, these authors also demonstrated, as we did here, that CD19+B220 low/neg B1 progenitor cells achieve a mature phenotype $\left(\mathrm{CD} 19^{+} \mathrm{B} 220^{+}\right)$upon in vitro co-culture with a bone marrow stromal cell line (Yoshimoto et al. 2011).

The fact that the AF-B cells spontaneously produced and released IgM in vitro, strongly suggests that these cells most likely belong to the B1 B cell subset. Underlining this, we also showed that the vast majority of AF-B cells express the B1 B cell marker CD5 (Montecino-Rodriguez \& Dorshkind 2012).

Overall, the results obtained in our work strongly suggest that the AF contains B1 progenitors as well as B1 B cells in advanced stages of their development.
Besides providing nutrients and growth factors as well as conferring mechanical protection to the fetus during pregnancy, the amniotic fluid represents a critical immunological barrier against invading pathogens (Davis et al. 1983, Schmidt 1992). Indeed, it has been recently demonstrated that numbers of AF immune cells are increased upon maternal infection or inflammation (Gomez-Lopez et al. 2018b). In keeping with this, using a mouse model of LPS-induced preterm birth, we showed here that percentages as well as total numbers of $\mathrm{CD}^{2}{ }^{+} \mathrm{B}$ cells were increased in the acute phase of preterm birth. Moreover, we additionally showed that the increase observed in total B cell percentages in the AF upon maternal challenge with LPS was conducted by an increase in the percentages of $\mathrm{CD}^{2} 9^{+} \mathrm{B} 220^{+}$ mature B1 B cells. These results reinforce the idea of AF-B1 B cells as critical immune component of the fetus's defense against maternal infections. Indeed, B1 $B$ cells are considered innate-like immune cells that mediate the first line of defense against pathogens (Baumgarth 2011). They respond rapidly to bacteria or 
bacterial components like LPS and differentiate into IgM-producing cells (Nguyen et al. 2015). In addition, B1 B cells are the major source of IgM natural antibodies which are spontaneously produced in the absence of foreign antigens and play a critical role in providing immune protection from pathogens (Berland \& Wortis 2002, Baumgarth 2011). Interestingly, we showed here that B1 B cells not only proliferate in the AF of pregnant mice that were systemically challenged with LPS but also spontaneously produce $\lg M$ in vitro.

In summary, we provided evidences in this work demonstrating the presence of B1 B cells, most likely of embryonic origin, in different stages of their development, in the amniotic fluid of pregnant mice. These AF-B1 B cells have the potential to grow and mature in vitro as well as show activation upon LPS stimulation and spontaneously produce IgM. This gives new insight into the role of B1 B cells within the AF as immunologically active barrier. In addition to this, the significant increase of B1 B cells, especially of their mature immunoglobulin-producing phenotype, in LPSinduced preterm birth suggests the importance of these cells in pathological pregnancies.

Even though further works are needed, this paves the way for deeper investigations of the function and protective capacity of the AF-B1 B cells in the context of pregnancy.

\section{Declaration of interest}

The authors declare that there is no conflict of interest that could be perceived as prejudicing the impartiality of the research reported.

\section{Funding}

This work was supported by research grants from the Fritz Thyssen Foundation (Az. 10.12.2.155), PRH-PICT (2016/004), PICT (2016-201-0151) all to F J and internal founding from the University of Greifswald assigned to the Department of Obstetrics and Gynecology, Medical Faculty, Greifswald University.

\section{Author contribution statement}

B I, J L and M D performed experiments, analyzed data and contributed to draft the manuscript; $V N, E J, M F, Z K, M K$ and V M S performed experiments; Z M contributed with reagents; J F conceived the working hypothesis, designed the experiments, supervised the work, wrote the manuscript and provided financial supports.

\section{Acknowledgements}

The authors would like to thank Diana Krüger for her excellent technical assistance in generating this work.
The results in this paper, apart from those displayed in Fig. 6, are part of the dissertation of Imke Bommer in order to obtain the degree Dr. med. at the University of Greifswald, Germany.

\section{References}

Arenas-Hernandez M, Romero R, Xu Y, Panaitescu B, Garcia-Flores V, Miller D, Ahn H, Done B, Hassan SS, Hsu CD et al. 2019 Effector and activated $\mathrm{T}$ cells induce preterm labor and birth that is prevented by treatment with progesterone. Journal of Immunology 202 2585-2608. (https://doi.org/10.4049/jimmunol.1801350)

Baumgarth N 2011 The double life of a B-1 cell: self-reactivity selects for protective effector functions. Nature Reviews: Immunology 11 34-46. (https://doi.org/10.1038/nri2901)

Berland R \& Wortis HH 2002 Origins and functions of B-1 cells with notes on the role of CD5. Annual Review of Immunology 20 253-300. (https:// doi.org/10.1146/annurev.immunol.20.100301.064833)

Davis LE, McLaren LC, Stewart JA, James CG, Levine MD \& Skipper BJ 1983 Immunological and microbiological studies of midtrimester amniotic fluid. Gynecologic and Obstetric Investigation 16 261-268. (https://doi.org/10.1159/000299275)

Galask RP \& Snyder IS 1970 Antimicrobial factors in amniotic fluid. American Journal of Obstetrics and Gynecology 106 59-65. (https://doi. org/10.1016/0002-9378(70)90126-2)

Gomez-Lopez N, Romero R, Arenas-Hernandez M, Ahn H, Panaitescu B, Vadillo-Ortega F, Sanchez-Torres C, Salisbury KS \& Hassan SS 2016 In vivo T-cell activation by a monoclonal $\alpha C D 3 \varepsilon$ antibody induces preterm labor and birth. American Journal of Reproductive Immunology 76 386390. (https://doi.org/10.1111/aji.12562)

Gomez-Lopez N, Romero R, Arenas-Hernandez M, Schwenkel G, St Louis D, Hassan SS \& Mial TN 2017 In vivo activation of invariant natural killer T cells induces systemic and local alterations in T-cell subsets prior to preterm birth. Clinical and Experimental Immunology 189 211-225. (https://doi.org/10.1111/cei.12968)

Gomez-Lopez N, Romero R, Maymon E, Kusanovic JP, Panaitescu B, Miller D, Pacora P, Tarca AL, Motomura K, Erez O et al. 2018 a Clinical chorioamnionitis at term IX: in vivo evidence of intra-amniotic inflammasome activation. Journal of Perinatal Medicine 47 276-287. (https://doi.org/10.1515/jpm-2018-0271)

Gomez-Lopez N, Romero R, Xu Y, Miller D, Leng Y, Panaitescu B, Silva P, Faro J, Alhousseini A, Gil N et al. 2018b The immunophenotype of amniotic fluid leukocytes in normal and complicated pregnancies. American Journal of Reproductive Immunology 79 e12827. (https://doi. org/10.1111/aji.12827)

Hardy RR \& Hayakawa K 2001 B cell development pathways. Annual Review of Immunology 19 595-621. (https://doi.org/10.1146/annurev. immunol.19.1.595) (available at: http://www.annualreviews.org/doi/ abs/10.1146/annurev.immunol.19.1.595)

Huang B, Faucette AN, Pawlitz MD, Pei B, Goyert JW, Zhou JZ, El-Hage NG, Deng J, Lin J, Yao F et al. 2017 Interleukin-33-induced expression of PIBF1 by decidual B cells protects against preterm labor. Nature Medicine 23 128-135. (https://doi.org/10.1038/nm.4244)

Jensen F, Wallukat G, Herse F, Budner O, El-Mousleh T, Costa SD, Dechend R \& Zenclussen AC 2012 CD19+CD5+ cells as indicators of preeclampsia. Hypertension 59 861-868.

Ji J, Vijayaragavan K, Bosse M, Menendez P, Weisel K \& Bhatia M 2008 OP9 stroma augments survival of hematopoietic precursors and progenitors during hematopoietic differentiation from human embryonic stem cells. Stem Cells 26 2485-2495. (https://doi.org/10.1634/ stemcells.2008-0642)

Kaga N, Katsuki Y, Obata M \& Shibutani Y 1996 Repeated administration of low-dose lipopolysaccharide induces preterm delivery in mice: a model for human preterm parturition and for assessment of the therapeutic ability of drugs against preterm delivery. American Journal of Obstetrics and Gynecology 174 754-759. (https://doi.org/10.1016/ S0002-9378(96)70460-X)

Kincade PW, Medina KL, Smithson G \& Scott DC 1994 Pregnancy: a clue to normal regulation of B lymphopoiesis. Immunology Today $\mathbf{1 5}$ 539-544.

Larsen B, Cheng HF \& Galask RP 1979 Bacterial growth inhibition by amniotic fluid. VIII. Evaluation of a radiometric bioassay for rapid, in 
vitro demonstration of phosphate-sensitive bacterial growth inhibitor in amniotic fluid. American Journal of Obstetrics and Gynecology 135 14-21.

Leng $\mathrm{Y}$, Romero R, Xu Y, Galaz J, Slutsky R, Arenas-Hernandez M, Garcia-Flores V, Motomura K, Hassan SS, Reboldi A et al. 2019 Are $\mathrm{B}$ cells altered in the decidua of women with preterm or term labor? American Journal of Reproductive Immunology 81 e13102. (https://doi. org/10.1111/aji.13102)

Lund FE 2008 Cytokine-producing B lymphocytes - key regulators of immunity. Current Opinion in Immunology 20 332-338. (https://doi. org/10.1016/j.coi.2008.03.003) (available at: http://linkinghub.elsevier. com/retrieve/pii/S0952791508000277)

Medina KL, Smithson G \& Kincade PW 1993 Suppression of B lymphopoiesis during normal pregnancy. Journal of Experimental Medicine 178 1507-1515.

Montecino-Rodriguez E \& Dorshkind K 2012 B-1 B cell development in the fetus and adult. Immunity 36 13-21. (https://doi.org/10.1016/j. immuni.2011.11.017)

Montecino-Rodriguez E, Leathers H \& Dorshkind K 2006 Identification of a B-1 B cell-specified progenitor. Nature Immunology 7 293-301. (https://doi.org/10.1038/ni1301)

Muzzio DO, Soldati R, Ehrhardt J, Utpatel K, Evert M, Zenclussen AC, Zygmunt M \& Jensen F 2014 B cell development undergoes profound modifications and adaptations during pregnancy in mice. Biology of Reproduction 91115.

Nguyen TTT, Elsner RA \& Baumgarth N 2015 Natural IgM prevents autoimmunity by enforcing B cell central tolerance induction. Journal of Immunology 194 1489-1502. (https://doi.org/10.4049/ jimmunol.1401880)

Niemelä A, Kulomaa M, Vilja P, Tuohimaa P \& Saarikoski S 1989 Lactoferrin in human amniotic fluid. Human Reproduction 4 99-101. (https://doi. org/10.1093/oxfordjournals.humrep.a136854)

Pieper K, Grimbacher B \& Eibel H 2013 B-cell biology and development. Journal of Allergy and Clinical Immunology 131 959-971. (https://doi. org/10.1016/j.jaci.2013.01.046)

Pierce J, Jacobson P, Benedetti E, Peterson E, Phibbs J, Preslar A \& Reems JA 2016 Collection and characterization of amniotic fluid from scheduled C-section deliveries. Cell Tissue Bank 17 413-425. (https:// doi.org/10.1007/s10561-016-9572-7)
Romero R, Chaiworapongsa T, Alpay Savasan Z, Xu Y, Hussein Y, Dong Z, Kusanovic JP, Kim CJ \& Hassan SS 2011 Damage-associated molecular patterns (DAMPs) in preterm labor with intact membranes and preterm PROM: a study of the alarmin HMGB1. Journal of Maternal-Fetal and Neonatal Medicine 24 1444-1455. (https://doi.org/10.3109/14767058 .2011.591460)

Schlievert P, Johnson W \& Galask RP 1976 Isolation of a low molecular weight antibacterial system from human amniotic fluid. Infection and Immunity $\mathbf{1 4}$ 1156-1166.

Schlievert P, Johnson W \& Galask RP 1977 Amniotic fluid antibacterial mechanisms: newer concepts. Seminars in Perinatology 1 59-70. (available at: http://europepmc.org/abstract/MED/370990)

Schmidt W 1992 The amniotic fluid compartment: the fetal habitat. Advances in Anatomy, Embryology and Cell Biology 127 1-100.

Tafari N, Ross SM, Naeye RL, Galask RP \& Zaar B 1977 Failure of bacterial growth inhibition by amniotic fluid. American Journal of Obstetrics and Gynecology 128 187-189. (https://doi.org/10.1016/00029378(77)90685-8)

Underwood MA, Gilbert WM \& Sherman MP 2005 Amniotic fluid: not just fetal urine anymore. Journal of Perinatology 25 341-348. (https://doi. org/10.1038/sj.jp.7211290)

Yoshimoto M, Montecino-Rodriguez E, Ferkowicz MJ, Porayette P, Shelley WC, Conway SJ, Dorshkind K \& Yoder MC 2011 Embryonic day 9 yolk sac and intra-embryonic hemogenic endothelium independently generate a B-1 and marginal zone progenitor lacking B-2 potential. PNAS 108 1468-1473. (https://doi.org/10.1073/pnas.1015841108)

Ziegler KB, Muzzio DO, Matzner F, Bommer I, Ventimiglia MS, Malinowsky K, Ehrhardt J, Zygmunt M \& Jensen F 2018 Human pregnancy is accompanied by modifications in B cell development and immunoglobulin profile. Journal of Reproductive Immunology 129 $40-47$.

Received 1 April 2019

First decision 3 May 2019

Revised manuscript received 8 August 2019

Accepted 27 August 2019 